\title{
Adam Pachucki
}

\section{(Nie)zatarte skazanie osoby ubiegającej się o pozwolenie na broń - analiza przypadku}

\begin{abstract}
ABSTRAKT
Zgodnie z polskim prawem osoba ubiegająca się o pozwolenie na broń (autor posługuje się przykładem sprawy osoby ubiegającej się o pozwolenie na broń myśliwską do celów łowieckich) musi wraz z wnioskiem przedłożyć orzeczenia lekarskie i psychologiczne, które stwierdzają, że może ona dysponować bronią. Orzeczenia takie mogą zostać zakwestionowane w drodze odwołania przez właściwego komendanta wojewódzkiego policji, który jako podstawę odwołania wskaże wyłącznie fakt zatartego skazania i będzie z tego wywodził rzekomą wadliwość orzeczeń, mimo braku posiadania jakichkolwiek innych zarzutów, dowodów lub informacji o tym, że kandydat nie powinien mieć broni. Zgodnie z prawem zatarte skazanie nie rodzi negatywnych skutków prawnych, wpis o skazaniu usuwa się z rejestru skazanych, a samo skazanie uznaje się za niebyłe. Autor na podstawie aktualnego orzecznictwa omawia kwestie płynące z obecnego brzmienia przepisów, pokazuje możliwe nadużycia, wskazuje na naruszenie instytucji zatarcia skazania oraz proponuje zmiany w przepisach, które mogłyby ograniczyć poruszone w artykule problemy.
\end{abstract}

\section{SŁOWA KLUCZOWE}

pozwolenie na broń, prawo dostępu do broni, zatarcie skazania, orzeczenie lekarskie lub psychologiczne osoby ubiegającej się o pozwolenie na broń, odwołanie w postępowaniu administracyjnym

\section{(Not)expunged criminal conviction of a person applying for a firearms license - a case study}

ABSTRACT

Under Polish law a person applying for a firearms license (the author uses the example of a person applying for a firearms license for hunting purposes) is obliged to attach thereto medical and psychological certificates confirming that an applicant may bear a firearm. These certificates may be challenged on appeal by the competent police authority, only on the grounds of an expunged conviction. Police authority can legally state that such conviction itself implies a defectiveness thereof, despite the lack of any other allegations, evidence or information that the candidate should not keep and bear a firearm. According to the law, an expunged conviction should not have any negative legal consequences, the record of the sen- 
tence is deleted from the register of offenders, and such conviction shall be considered void. Based on the current jurisprudence, the author discusses the problems of the current wording of the legal provisions, shows possible abuses, indicates the violation of the institution of expungement and proposes changes to the provisions that could reduce the problems mentioned in the article.

\section{KEYWORDS}

a firearms license, a right to keep and bear arms, expungement of a criminal record, medical or psychological certificate of the firearms license applicant, appeal in administrative proceedings

\section{Wprowadzenie - zarysowanie problemu w ramach wybranego postępowania}

Praktycznie każdy słyszał o instytucji zatarcia skazania. Ma ona istotne znaczenie nie tylko na gruncie szeroko rozumianego prawa karnego, lecz także w ramach różnych postępowań o charakterze administracyjnym, w których wymaga się, aby określona osoba legitymowała się niekaralnością (niekaralnością w ogóle, niekaralnością za określone przestępstwo) ${ }^{1}$.

Przykładem takiego postępowania jest procedura prowadzona przed właściwym organem (w znamienitej większości przypadków będzie to właściwy miejscowo komendant wojewódzki policji) w przedmiocie pozwolenia na broń łowiecką do celów myśliwskich. Artykuł 15 ust. 1 pkt 6 lit. a-b ustawy z 21 maja 1999 r. o broni i amunicji (tekst jednolity: Dz.U. z 2020 r. poz. 955; dalej: UBA) wyraźnie stanowi, że pozwolenia na broń nie wydaje się osobom skazanym prawomocnym orzeczeniem sądu za umyślne przestępstwo lub umyślne przestępstwo skarbowe, a także skazanym prawomocnym orzeczeniem sądu za nieumyślne przestępstwo przeciwko życiu i zdrowiu, przeciwko bezpieczeństwu w komunikacji popełnione w stanie nietrzeźwości bądź pod wpływem środka odurzającego albo gdy sprawca zbiegł z miejsca zdarzenia.

Problem, który zarysowuje się na gruncie faktu zatartego skazania w kontekście postępowania administracyjnego, wymaga nakreślenia pewnego tła - niezbędne jest przywołanie konkretnego przypadku.

Pewien wieloletni myśliwy został skazany za przestępstwo polegające na uporczywym nękaniu drugiej osoby (tzw. stalking, art. 190a $\$ 1 \mathrm{KK}$ ). Wobec skazania za umyślne przestępstwo (na marginesie można wskazać, że nie pozostawało ono w związku z użyciem broni) stosowną decyzją cofnięto mu pozwolenie na broń myśliwską do celów łowieckich (art. 18 ust. 1 pkt 2 w zw. z art. 15 ust. 1 pkt 6 lit. a oraz art. 20 UBA) $)^{2}$ Z upływem czasu doszło do zatarcia skazania, a myśliwy (tzw. osoba ubiegająca się, wnioskodawca) złożył wniosek o wydanie mu pozwolenia na broń myśliwską do celów łowieckich - dopełniwszy wszystkich wymogów formalnych.

Osoba, która występuje z wnioskiem o wydanie pozwolenia na broń, przedstawia właściwemu organowi orzeczenia lekarskie i psychologiczne (art. 15 ust. 3 w zw. z art. 15a

1 Stefańska, B., Zatarcie skazania. Warszawa 2014, s. 35-38, 54, 73-74.

2 Wyrok NSA z 19 stycznia 2018 r., II OSK 781/16, Legalis nr 1716534. 
ust. 1 UBA). Zgodnie z art. 15a ust. 2 UBA musi przejść badanie lekarskie, które obejmuje ogólną ocenę stanu zdrowia, ze szczególnym uwzględnieniem układu nerwowego, stanu psychicznego, stanu narządów wzroku, słuchu i równowagi oraz sprawności układu ruchu. Przeprowadzający je lekarz kieruje osobę ubiegającą się na badania psychiatryczne i okulistyczne, a jeżeli uzna to za niezbędne - na inne badania specjalistyczne lub pomocnicze. Zgodnie z art. 15a ust. 3 i 4 UBA badanie psychologiczne osoby ubiegającej się obejmuje w szczególności określenie poziomu rozwoju intelektualnego i opis cech osobowości, $\mathrm{z}$ uwzględnieniem funkcjonowania $\mathrm{w}$ trudnych sytuacjach, a także określenie poziomu dojrzałości społecznej tej osoby. Zakres badania psychologicznego może zostać rozszerzony, jeżeli przeprowadzający je psycholog uzna to za niezbędne do prawidłowego określenia sprawności psychologicznej osoby ubiegającej się.

Wracając do naszego przypadku, wnioskodawca przedłożył pozytywne orzeczenie lekarskie i psychologiczne - innymi słowy, uprawniony lekarz i uprawniony psycholog nie stwierdzili żadnych przeciwwskazań do dysponowania bronią. We wniosku zostały przedstawione ważne powody (przyczyny) posiadania broni.

$\mathrm{W}$ toku postępowania $\mathrm{w}$ przedmiocie wydania pozwolenia na broń myśliwską do celów łowieckich, powołując się na art. 15h ust. 1 i 2 UBA, funkcjonariusz upoważniony w trybie art. 286a KPA wniósł w imieniu komendanta wojewódzkiego policji odwołania od obu ww. orzeczeń - psychologicznego i lekarskiego. W krótkim uzasadnieniu podano, że jedyną przyczyną zakwestionowania orzeczeń lekarskich jest fakt, że osoba ubiegająca się o pozwolenie na broń była w przeszłości skazana, a co za tym idzie, zachodzi uzasadnione podejrzenie, że ukryła ten fakt przed lekarzem i psychologiem w trakcie badań, co mogło skutkować uzyskaniem pozytywnych (korzystnych) dla niej orzeczeń. Przedmiotowe skazanie zostało opisane w taki sposób, jakby było skazaniem aktywnym (niezatartym). Pomijając podstawę prawną i opis wyroku, którego dotyczyło skazanie, to przedmiotowe uzasadnienia odwołań były tożsame i jednozdaniowe.

Orzeczenia lekarskie i psychologiczne, które dołącza się do wniosku o wydanie pozwolenia na broń, nie zawierają uzasadnienia. Ograniczają się do wskazania podstawy prawnej i stwierdzenia, czy dana osoba może posiadać broń czy też nie.

W toku badania ubiegający się mógł w ramach wywiadu oświadczyć, że jest osobą niekaraną - co byłoby zgodne z prawdą i do czego był w pełni uprawniony. Ponieważ funkcjonariusz w odwołaniach powołał się na rzekome zatajenie skazania oraz niczym niepoparte przypuszczenia, że doszło do ukrywania faktu skazania (co nie miało miejsca, gdyż ubiegający się podał tę informację w wywiadzie), po pisemnym sprzeciwie wnioskodawcy organ sprostował ww. odwołania, dodając informację o tym, że „skazanie uległo zatarciu”.

Załączony do akt postępowania wywiad środowiskowy potwierdził, że osoba ubiegająca się o pozwolenie na broń ma dobrą opinię, jest aktywna życiowo i zawodowo, nie ma żadnej niepełnosprawności, prawidłowo funkcjonuje w społeczeństwie, nie nadużywa alkoholu, nie ma kontaktów $\mathrm{z}$ elementem przestępczym. 


\section{Problem}

Z powyższego stanu faktycznego wyłania się następujący problem - czy fakt zatartego skazania, przy braku sformułowania jakichkolwiek zastrzeżeń do przebiegu badań i kompetencji lekarza bądź psychologa, może stanowić samodzielną i wystarczającą podstawę wniesienia odwołania od orzeczenia lekarskiego sporządzanego w ramach ubiegania się o pozwolenie na broń.

Problem, który możemy dostrzec w opisanym powyżej stanie faktycznym, jest poważniejszy i bardziej złożony, niż mogłoby się wydawać. Co ważne, wpisuje się on także we wskazywaną w literaturze kwestię coraz bardziej zbiurokratyzowanego procesu szeroko rozumianej reglamentacji broni (w tym palnej) - angażującej coraz więcej instytucji, którym czasem zarzuca się zajmowanie zagadnieniami wykraczającymi poza zakres ich działalności $^{3}$. W mojej ocenie sprawę tę powinno się rozpatrywać przede wszystkim przez pryzmat orzecznictwa - jako najbardziej odzwierciedlającego praktykę stosowania przepisów. Omawiany problem ma też charakter przede wszystkim praktyczny.

W świetle prawa skazanie zatarte uznaje się za niebyłe (art. $106 \mathrm{KK}$ ). Od tej chwili nie może ono wywoływać żadnych negatywnych skutków prawnych dla skazanego, choć wcześniej skazanie to istniało i miało określone skutki wynikające $\mathrm{z}$ treści wyroku ${ }^{4}$. Z zatarciem skazania sprawca nie tylko może się uważać za "nieskazanego" czy niekaranego, lecz także za osobę, która nie dopuściła się popełnienia przestępstwa, a więc nie naruszyła zakazów bądź nakazów prawnokarnych. Co więcej, w części doktryny przyjmuje się, że od momentu zatarcia skazania należy przyjmować, że „skazanie jako zdarzenie nie miało w ogóle miejsca" ${ }^{5}$. Oczywiście nie znaczy to, iż przestępstwo w przeszłości nie miało w ogóle miejsca (nie doszło do jego popełnienia). Oznacza jedynie, że od chwili zatarcia skazania skazany ma status osoby niekaranej. Skuteczność tej zasady aktualizuje się wraz z nastąpieniem zatarcia skazania, tj. nie wcześniej i nie później, a nadto ma ono skutek „na przyszłość”.

W orzecznictwie sądów administracyjnych z jednej strony podkreśla się, że istotnie jest tak, iż skazanie zatarte nie może rodzić żadnych negatywnych konsekwencji prawnych ${ }^{7}$, a powoływanie się $\mathrm{w}$ uzasadnieniu na popełnienie przestępstw, które już uległy zatarciu, nie może stanowić negatywnej przesłanki w przedmiocie odmowy wydania zainteresowanemu pozwolenia na broń palną ${ }^{8} \mathrm{Z}$ drugiej strony wydawane są orzeczenia, zgodnie z którymi organy administracji $\mathrm{w}$ toku postępowania są $\mathrm{w}$ pełni uprawnione do uwzględniania przestępstw, mimo że skazania za nie uległy zatarciu'. Ta druga linia orzecznicza w literaturze oceniana jest jednak jako błędna - nie można brać bowiem pod uwagę czegoś, czego

3 Babiński, A., Prawno-organizacyjne uwarunkowania bezpieczeństwa i porządku publicznego w zakresie dostępu do broni. Wprowadzenie do problematyki. Szczytno 2017, s. 6-7, 88-93, 110-119.

4 Postanowienie SN z 22 października 2020 r., I KS 13/20, Legalis nr 2489770.

5 Grześkowiak, A., Komentarz do art. 106 KK, w Grześkowiak, A. i Wiak, K. (red.), Kodeks karny. Komentarz. Warszawa 2021, teza 5. Legalis/el.

6 Postanowienie SN z 3 marca 2020 r., II PK 36/19, Legalis nr 2414589.

7 Wyrok WSA w Warszawie z 20 marca 2013 r., II SA/Wa 268/13, Legalis nr 678863.

8 Wyrok WSA w Warszawie z 20 lipca 2020 r., II SA/Wa 2277/19, Legalis nr 2512165.

9 Wyrok NSA z 19 lutego 2020 r., II OSK 973/18, Legalis nr 2514604. 
de facto i de iure nie ma, zwłaszcza jeśli dodatkowo zwróci się uwagę na to, że istota zatarcia skazania opiera się na idei przywrócenia dobrej opinii społecznej, pełni uprawnień w życiu społecznym i nieutrzymywania w nieskończoność obciążenia sprawcy konsekwencjami popełnionego przestępstwa ${ }^{10}$.

Należy zasygnalizować, że czym innym jest powoływanie się na zaistnienie czy występowanie przesłanek negatywnych z art. 15 ust. 1 pkt 6 lit. a-b UBA, a czym innym wywodzenie, że wnioskodawca (osoba ubiegająca się o broń) stanowi zagrożenie dla samego siebie, porządku lub bezpieczeństwa publicznego - co jest pośrednio wywodzone z uprzednich skazań, ale jednak wymaga pogłębionego postępowania dowodowego.

Zgodnie z orzecznictwem zatarcie skazania pozwala określoną osobę uznać za niekaraną, jednakże przy ocenie jej osobowości jako pewnej całości ważny będzie nie tyle fakt skazania bądź nie, ile dotychczasowe życie i sposób postępowania tej osoby. W świetle aktualnie obowiązujących przepisów prawa materialnego samo skazanie nie może być samoistną podstawą do odmowy wydania pozwolenia na broń, ale w powiązaniu $\mathrm{z}$ innymi okolicznościami może wskazywać, że osoba ubiegająca się o pozwolenie potencjalnie stanowi zagrożenie dla porządku i bezpieczeństwa publicznego (co jednak będzie wymagało szerszego zbadania) $)^{11}$.

Z powyższego zestawienia orzeczeń płynie wniosek, że pomimo zatarcia kary (skazania) można w toku postępowania uznać, że wnioskodawca jest zagrożeniem dla porządku i bezpieczeństwa publicznego, jeżeli inne dowody, w tym wywiad środowiskowy, wskazują, iż jest on osobą niebezpieczną. Podobnie uznaje się, że brak jest podstawy do wydania pozwolenia, gdy wobec wnioskodawcy co prawda zatarto karę za pewne przestępstwo, ale nadal toczy się przeciwko niemu inne, kolejne postępowanie karne lub wnioskodawca był karany za wykroczenia przeciwko życiu bądź zdrowiu ${ }^{12}$.

Co jednak w sytuacji, gdy w określonym postępowaniu, w danej sprawie, zatarte skazanie jest jedynym „argumentem negatywnym”? Jeśli nie występują żadne dowody niekorzystne dla osoby ubiegającej się o pozwolenie na broń - a wręcz całokształt materiału dowodowego przekonuje, że ogólna ocena jest pozytywna - to należy się zastanowić, czy organ jest w ogóle uprawniony do wykorzystania w jakikolwiek sposób zatartego skazania. W szczególności dotyczy to właśnie możliwości skutecznego wniesienia odwołania od orzeczeń lekarskich lub psychologicznych (art. 15h UBA) wyłącznie na podstawie faktu uprzedniego skazania - co miało miejsce w opisanej powyżej sprawie (postępowaniu).

Wobec braku sformalizowania w KPA środka odwoławczego, jakim jest odwołanie, dla jego skutecznego złożenia wystarczy w zasadzie wyraźne wyrażenie niezadowolenia z treści rozstrzygnięcia ${ }^{13}$. Każde pismo strony dotyczące decyzji nieostatecznej (tu orzeczenia lekarskiego, psychologicznego) wniesione w terminie otwartym do wniesienia odwołania,

10 Stefańska, B., op. cit., s. 187-193, 224-226.

11 Wyrok NSA z 22 października 2019 r., II OSK 1479/19, Legalis nr 2291728; także: Wyrok NSA z 30 października 2018 r., II OSK 2652/16, Legalis nr 1854832.

12 Wyrok NSA z 14 listopada 2019 r., II OSK 3221/17, Legalis nr 2254656.

13 Wyrok NSA z 8 października 2020 r., II OSK 1724/20, Legalis nr 2490029. 
wyrażające jej niezadowolenie, winno być traktowane jako odwołanie ${ }^{14}$ - co jest zgodne $\mathrm{z}$ art. $128 \mathrm{KPA}$. Element wyrażenia niezadowolenia z decyzji czy orzeczenia wydanego w pierwszej instancji w świetle tego przepisu jest konieczny do zakwalifikowania danego pisma jako odwołania - to musi wynikać z jego treści $i^{15}$. Jednocześnie - zgodnie z art. 63 $\$ 2 \mathrm{KPA}$ - odwołanie (będące podaniem w rozumieniu KPA) powinno zawierać żądanie strony odwołującej się $e^{16}$. Przepis art. $128 \mathrm{KPA}$ stanowi ponadto, że przepisy szczególne mogą ustalać inne, dodatkowe wymogi co do treści odwołania. Jeśli przepis art. 15h ust. 3 UBA wyraźnie wprowadza wymóg uzasadnienia odwołania, to wolą ustawodawcy jest, aby miało ono zasadne podstawy i opierało się na argumentach i dowodach, z których wynika wskazane w ww. przepisie "niezadowolenie”.

Czy sam fakt zatartego skazania jest wystarczającą przesłanką do kwestionowania pozytywnych orzeczeń lekarskich bądź psychologicznych - bez jakichkolwiek zarzutów względem orzeczeń? Jakie żądanie stoi za takim odwołaniem: czy organ domaga się zweryfikowania tylko okoliczności „zatajenia zatartego skazania”, czy też formułuje inne żądanie, kontestując $\mathrm{w}$ ten sposób całe orzeczenie lekarskie lub psychologiczne? Jak rozumieć odwołanie, które powołuje się wyłącznie na zatarte skazanie? Zdaje się, że aktualne brzmienie przepisów związanych z wnoszeniem odwołań od orzeczeń lekarskich bądź psychologicznych pozwala na swoiste obejście (na etapie postępowania poprzedzającego wydanie decyzji) regulacji dotyczących zatarcia i stanowi pretekst, aby organ mógł nie wydać pozwolenia na broń.

\section{Analiza problemu}

Wydaje się, że zatarte skazanie nie ma bezpośredniego związku z badaniem lekarskim czy psychologicznym - nie jest to okoliczność automatycznie podważająca przeprowadzone badania. Zatarte skazanie nie wyklucza otrzymania pozytywnego orzeczenia. Psycholog lub lekarz może mieć wiedzę o zatartym skazaniu, choć osoba badana może zgodnie z prawdą oświadczyć, że nie była nigdy karana, i ta okoliczność nie powinna być dalej weryfikowana.

Orzeczenia lekarskie albo psychologiczne wydane w trybie odwoławczym są ostateczne (art. 15h ust. 7 UBA). Możliwa jest sytuacja, w której uprawniony przedstawi pozytywne orzeczenia na etapie składania wniosku, ale $\mathrm{w}$ toku procedury odwoławczej wydane zostaną orzeczenia negatywne. Wpłynąć na to mogą: zasugerowanie przez organ uprzedniego skazania, uwypuklenie opisu czynu (badający w trybie odwoławczym specjalista będzie zapewne szczególnie drążył ten temat) czy innego rodzaju niekorzystne przedstawienie osoby, której odwołanie dotyczy.

W odniesieniu do ostatecznego charakteru orzeczeń lekarskich lub psychologicznych orzecznictwo nie jest jednolite. $\mathrm{Z}$ jednej strony można zaprezentować stanowisko, że or-

\footnotetext{
14 Wyrok WSA w Poznaniu z 19 września 2019 r., II SA/Po 293/19, Legalis nr 2235397.

15 Glibowski, K., Komentarz do art. 128 KPA, w Hauser, R. i Wierzbowski, M. (red.), Kodeks postępowania administracyjnego. Komentarz. Warszawa 2020, tezy 2-3. Legalis/el.

16 Ibidem, teza 10. Legalis/el.
} 
gany policji nie są uprawnione do oceny przyczyn, dla których kompetentny lekarz orzekł o braku zdolności do posiadania przez stronę broni. Nie wiedzą, które z wymaganych do wydania orzeczenia badań cząstkowych miało wpływ na jego treść, nie mają również kompetencji do weryfikowania zasadności orzeczenia wydania osobie ubiegającej się o broń lub już ją posiadającej ani też do wyjaśniania rozbieżności pomiędzy orzeczeniami wystawionymi przez lekarzy albo psychologów zarówno w I, jak i w II instancji ${ }^{17}$. Z drugiej zaś strony pojawiają się głosy, zgodnie z którymi organy winny oceniać orzeczenia wydane w trybie odwoławczym - pomimo ich ostatecznego charakteru. Nie jest bowiem dopuszczalne w demokratycznym państwie prawa, aby dowód, i to o wiążącym charakterze, pozostawał poza jakąkolwiek kontrolą i oceną, a co za tym idzie, uchylając się od oceny orzeczenia w zakresie wyżej określonym, organy naruszają przepisy postępowania administracyjnego - art. 7, art. $75 \S 1$ i art. $77 \S 1 \mathrm{KPA}$, a także przepisy regulujące prowadzenie tych badań ${ }^{18}$.

Powyższe prowadzi do pewnej dwoistości i możliwości niezasadnego kwestionowania jednego orzeczenia (pierwszego) przy jednoczesnej odmowie możliwości ocenienia kolejnego orzeczenia (wydanego w trybie odwołania). W aktualnym brzmieniu przepisów organ może praktycznie arbitralnie uruchomić procedurę odwoławczą wobec jednego orzeczenia, a w odniesieniu do innego, tożsamego w swym przedmiocie, będzie argumentował, że jest związany jego treścią. W literaturze co prawda wskazuje się, że organ administracji nie jest związany orzeczeniem lekarskim w takim stopniu, jak nie jest związany opinią biegłego, ponieważ to na organie, a nie na lekarzu (specjaliście) spoczywa obowiązek rozstrzygnięcia sprawy. Organ nie może więc przyjąć orzeczenia niepełnego, niekompletnego czy wydanego po nierzetelnym badaniu. To zaś oznacza, że chociaż nie jest niemożliwe powołanie biegłego na okoliczność ustalenia prawidłowości przeprowadzenia samych badań, czym innym jest jednak ocena materiału dowodowego przez organ wydający pozwolenie na broń, a czym innym ocena postępowania tego organu $\mathrm{z}$ materiałem dowodowym. Będą tu miały zastosowanie rozbieżne warunki oceny ${ }^{19}$.

\section{Próba rozwiązania problemu}

Organ w obu odwołaniach nie wskazywał żadnych zarzutów względem orzeczeń załączonych przez osobę ubiegającą się o broń, a jednocześnie brak było dowodów, że ubiegający leczył się psychiatrycznie lub miał jakiekolwiek kłopoty ze sprawnością psychofizyczną. Nie pojawiły się też nowe okoliczności (por. art. 15 ust. 1 pkt 2 i 4 UBA) ani dowody na problemy natury psychologicznej (por. art. 15 ust. 1 pkt 3 UBA). Nie było żadnych okoliczności podważających prawidłowość pierwotnych orzeczeń. Nie było innych dowodów świadczących na niekorzyść osoby ubiegającej się o pozwolenie na broń, że stanowi zagrożenie dla

17 Wyrok WSA w Warszawie z 28 lutego 2018 r., II SA/Wa 1448/17, Legalis nr 1759661.

18 Wyrok NSA z 6 kwietnia 2017 r., II OSK 2966/15, Legalis nr 1637796.

19 Pachnik, K., Zasady oceny dowodów w sprawach dotyczących wydawania i cofania pozwoleń na posiadanie broni $w$ postępowaniach przed organem i sądem administracyjnym, w Kwiatkowska-Wójcikiewicz, V. i Stępka, L. (red.), Broń. Problematyka prawna i kryminalistyczna. Toruń 2013, s. 83-84. 
samej siebie, porządku lub bezpieczeństwa publicznego - jednocześnie istniały ważne przyczyny posiadania broni.

Jak już było podnoszone powyżej, skoro wniesienie odwołania jest równoznaczne z negatywną oceną orzeczenia i opiera się na takiej czy innej wadliwości orzeczenia lekarskiego bądź psychologicznego - a w uzasadnieniu odwołań organu nie było jednak zarzutów do lekarza czy psychologa - to treść odwołania opartego wyłącznie na zatartym skazaniu jest wewnętrznie sprzeczna. Jako że nie doszło do rozpytania lekarza i psychologa czy innej formy uzyskania informacji lub weryfikacji okoliczności związanych z przebiegiem obu badań, organ nie miał jakichkolwiek podstaw ku temu, aby zasadnie przypuszczać, że lekarz i psycholog nie posiadali informacji zawartych w uzasadnieniach odwołań. Nie wiadomo, w jaki sposób organ uznał, że z faktu zatartego skazania, niby zatajonego, wynikają znaczne ograniczenie sprawności psychofizycznej albo występowanie zaburzeń psychicznych. Zakładanie rzekomego zatajenia skazania może wręcz sugerować złą wolę organu bądź pewne uprzedzenie względem osoby wnioskującej o wydanie jej pozwolenia na broń.

Moim zdaniem ocenę niewłaściwego działania organu wspiera piśmiennictwo:

W literaturze przyjmuje się, że obowiązek przedstawienia orzeczenia lekarskiego i psychologicznego ustawodawca nałożył na osobę posiadającą pozwolenie na broń w sytuacji, gdy ujawnione zostaną okoliczności dostatecznie uzasadniające podejrzenie, że cierpi ona na zaburzenia psychiczne albo wykazuje istotne zaburzenia funkcjonowania psychologicznego lub też jest uzależniona od alkoholu bądź substancji psychoaktywnych.

W takim przypadku właściwy organ Policji może (fakultatywnie) nałożyć na nią wspomniany obowiązek, a badanie takie musi być przeprowadzone niezwłocznie. Jednocześnie wskazuje się, że ocena, czy ujawnione okoliczności dostatecznie uzasadniają podejrzenie, iż osoba posiadająca broń lub zarejestrowaną broń pneumatyczną należy do osób, które nie mogą dysponować bronią, ma charakter oceny i musi być prawidłowo dokonana przez właściwy organ Policji.

Na pewno podstawą zażądania przedstawienia dodatkowego orzeczenia lekarskiego i psychologicznego nie może być plotka czy przypuszczenie ${ }^{20}$.

Podstawą wniesionych odwołań było wyłącznie arbitralne przypuszczenie organu - co zresztą wprost wyraził on w uzasadnieniach obu odwołań.

W orzecznictwie podkreśla się, że jeżeli strona w odwołaniu przedstawi swoje stanowisko, formułując konkretne zarzuty, to organ, rozpatrując sprawę, w pierwszej kolejności powinien ponownie się do nich odnieść ${ }^{21}$. Zgodnie z powyższym rozpatrujący odwołanie podmiot odwoławczy winien przede wszystkim odnieść się do zarzutu zatartego skazania. W realiach przedmiotowej sprawy sprowadzałoby się do tego, że lekarz czy psycholog wykonywałby swoją pracę na podstawie niebyłych z punktu widzenia prawa zdarzeń - badany byłby nieistniejący fakt - co w sposób oczywisty narusza zasadę uznawania za niebyłe

20 Kurzępa, B., Komentarz do art. 15, w Kurzępa, B., Ustawa o broni i amunicji. Komentarz. Warszawa 2010, teza 15. Legalis/el.

21 Wyrok NSA z 7 czerwca 2018 r., I GSK 745/18, Legalis nr 1813140. 
zatartych skazań oraz od samego początku narzuca określony kierunek badań podmiotu odwoławczego.

W tym miejscu warto przywołać wyrok Wojewódzkiego Sądu Administracyjnego w Olsztynie z 28 listopada 2019 r., w którym wyraźnie podkreślono, że od chwili zatarcia skazania prawdziwe - z punktu widzenia porządku prawnego - jest stwierdzenie, że danego przestępstwa nie popełniono ${ }^{22}$. Ważny jest również wyrok Wojewódzkiego Sądu Administracyjnego w Szczecinie z 19 września 2019 r., w którym sąd zauważył, że organ, opierając swe rozstrzygnięcia w sprawie na fakcie skazania skarżącego wyrokiem, który uległ zatarciu, narusza przepisy prawa w sposób mający (istotny) wpływ na wynik sprawy. Powoływanie się na wyrok skazujący, który uległ zatarciu, jest niedopuszczalne ${ }^{23}$.

\section{Podsumowanie - uwagi de lege ferenda}

Mogłoby się wydawać, że poruszony w niniejszym artykule problem nie powinien w ogóle mieć miejsca. Aktualne brzmienie przepisów sprawia jednak, że organ, mając możliwość uwzględniania zatartych skazań i powoływania się na nie, tak naprawdę skutecznie kwestionuje orzeczenia lekarskie czy psychologiczne, nie mając do tego zasadnych podstaw.

Ogólność regulacji dotyczących odwołań wnoszonych na podstawie KPA w połączeniu z ogólnością przepisów UBA sprawia, że zatarte skazanie może prowadzić do nadużyć, a wręcz być swoistym pretekstem do wywiedzenia odwołania. Brak wymogów zarówno co do treści odwołania, jak i jego uzasadnienia sprawia, że tak naprawdę w znacznej mierze od dobrej lub złej woli organu zależy to, czy wniesione zostanie odwołanie.

Powołanie się na zatarte skazanie i opisanie go w sposób sugerujący, że jest ono aktywne i niezatarte, wywołuje wrażenie poważnej i uzasadnionej podstawy odwołania - wydaje się czymś, co ma duże znaczenie. Nawet późniejsze sprostowanie odwołania o wzmiankę o zatarciu skazania i tak będzie miało zdecydowany wpływ na przebieg badań, obiektywizm oraz sposób postrzegania osoby ubiegającej się o pozwolenie na broń.

W mojej ocenie w ramach omawianego problemu wyraźnie widać fikcję zatarcia skazania oraz błędne koło faktycznego niezacierania się zatartego skazania. Należałoby się zastanowić, czy przepisy art. 15h UBA nie powinny wprowadzać ograniczeń i szczegółowszych wymogów w zakresie odwołań (na co zezwala art. 128 KPA). Poruszony problem zostałby w znacznej mierze ograniczony, a w niektórych przypadkach wręcz wyeliminowany poprzez wprowadzenie zapisu w ust. 1 cyt. artykułu, że „podstawą odwołania mogą być wyłącznie zarzuty co do kompetencji lekarza lub psychologa, o których mowa w art. 15b i 15c UBA, oraz zarzuty co do sposobu prowadzenia badań, o którym mowa w art. 15a ust. 2-4 UBA".

Mam świadomość, że w polskim porządku prawnym dostęp do broni ma charakter reglamentowany $^{24}$. Prawo jej posiadania nie należy też w Polsce do praw obywatelskich gwa-

22 II SA/Ol 734/19, Legalis nr 2260083.

23 II SA/Sz 432/19, Legalis nr 2247780.

24 Wyrok NSA z 14 listopada 2019 r., II OSK 3221/17, Legalis nr 2254656. 
rantowanych w Konstytucji $\mathrm{RP}^{25}$. Jednocześnie posiadanie i używanie broni w istotny sposób łączy się ze sferą psychiki (sprawcy, ofiar), przez co konieczne jest weryfikowanie stanu psychicznego i psychologicznego osoby o nią wnioskującej ${ }^{26}$. Powyższe nie zmienia jednak tego, że system prawny winien być spójny i uwzględniać zasady wyrażone w art. 8 ust. 1 i 2 KPA, w szczególności zasadę równości wobec prawa.

Jednorazowe i zatarte skazanie, o ile nie toczą się kolejne sprawy (o czym było powyżej), z punktu widzenia art. 8 ust. 2 KPA jest bez wątpienia takim samym stanem prawnym dla każdego, kogo dotyczy. Odwołanie winno mieć charakter rzeczowy ( $\mathrm{d} \mathrm{d} \mathrm{rem}$ ), a nie osobowy (ad personam), organ zaś powinien postępować w ten sam, utrwalony sposób. Przy obecnym kształcie regulacji i brzmieniu przepisów budzi to jednak uzasadnione wątpliwości, gdyż na przykład w odniesieniu do dwóch osób organ może co do jednej nie powołać się na zatarte skazanie (uznać je za niebyłe), co do drugiej natomiast skazanie takie może być wyłączną podstawą wniesienia odwołania od orzeczenia lekarskiego lub psychologicznego, co później będzie w sposób oczywisty rzutowało na treść ostatecznej decyzji.

\section{Bibliografia}

\section{Literatura}

Babiński, A., Prawno-organizacyjne uwarunkowania bezpieczeństwa i porządku publicznego w zakresie dostępu do broni. Wprowadzenie do problematyki. Szczytno 2017.

Grześkowiak, A. i Wiak, K. (red.), Kodeks karny. Komentarz. Warszawa 2021.

Hauser, R. (red.), Kodeks postępowania administracyjnego. Komentarz. Warszawa 2020.

Kurzępa, B., Ustawa o broni i amunicji. Komentarz. Warszawa 2010.

Pachnik, K., Zasady oceny dowodów w sprawach dotyczacych wydawania i cofania pozwoleń na posiadanie broni $w$ postępowaniach przed organem i sadem administracyjnym, w Kwiatkowska-Wójcikiewicz, V. i Stępka, L. (red.), Broń. Problematyka prawna i kryminalistyczna. Toruń 2013

Stefańska, B., Zatarcie skazania, Wolters Kluwer, Warszawa 2014.

\section{Akty prawne}

Ustawa z dnia 14 czerwca 1960 r. - Kodeks postępowania administracyjnego, Dz.U z 2020 r. poz. 256. Ustawa z dnia 6 czerwca 1997 r. - Kodeks karny, Dz.U. z 2020 r. poz. 1444.

Ustawa z dnia 21 maja 1999 r. o broni amunicji, Dz.U. z 2020 r. poz. 955.

\section{Orzecznictwo}

Postanowienie SN z 3 marca 2020 r., II PK 36/19, Legalis nr 2414589.

Postanowienie SN z 22 października 2020 r., I KS 13/20, Legalis nr 2489770.

Wyrok NSA z 6 kwietnia 2017 r., II OSK 2966/15, Legalis nr 1637796.

Wyrok NSA z 19 stycznia 2018 r., II OSK 781/16, Legalis nr 1716534.

Wyrok NSA z 7 czerwca 2018 r., I GSK 745/18, Legalis nr 1813140.

25 Wyrok NSA z 30 października 2018 r., II OSK 2653/16, Legalis nr 1864246.

26 Babiński, A., op. cit., s. 27-34. 
Wyrok NSA z 30 października 2018 r., II OSK 2652/16, Legalis nr 1854832.

Wyrok NSA z 30 października 2018 r., II OSK 2653/16, Legalis nr 1864246.

Wyrok NSA z 22 października 2019 r., II OSK 1479/19, Legalis 2291728.

Wyrok NSA z 14 listopada 2019 r., II OSK 3221/17, Legalis nr 2254656.

Wyrok NSA z 19 lutego 2020 r., II OSK 973/18, Legalis nr 2514604.

Wyrok NSA z 8 października 2020 r., II OSK 1724/20, Legalis nr 2490029.

Wyrok WSA w Olsztynie z 28 listopada 2019 r. II SA/Ol 734/19, Legalis nr 2260083.

Wyrok WSA w Poznaniu z 19 września 2019 r., II SA/Po 293/19, Legalis nr 2235397.

Wyrok WSA w Szczecinie z 19 września 2019 r., II SA/Sz 432/19, Legalis nr 2247780.

Wyrok WSA w Warszawie z 20 marca 2013 r., II SA/Wa 268/13, Legalis nr 678863.

Wyrok WSA w Warszawie z 28 lutego 2018 r., II SA/Wa 1448/17, Legalis nr 1759661.

Wyrok WSA w Warszawie z 20 lipca 2020 r., II SA/Wa 2277/19, Legalis nr 2512165. 